\title{
IN FORMAÇÕES OFFICIAES
}

Nomeações:- Foram nomeados, durante o corrente anno, os seguintes lentes:

-Dr. José Ulpiano Pinto de Souza, por Decreto de 27 de Janeiro, lente substituto da $4 .{ }^{a}$ Secção; tomou posse a 4 de Fevereiro.

-Dr. Candido Nazianzeno Nogueira da Motta, por Decreto de 19 de Abril, lente substituto da 5." Secção; tomou posse a 29 do mesmo mez.

-Dr. João Pedro da Veiga Filho, por Decreto de I 2 de Maio, foi nomeado lente cathedratico da $3 \cdot{ }^{a}$ cad. do $5 .^{\circ}$ anno; tomou posse a $1 .^{\circ}$ de Junho.

-Dr. José Mariano Correa de Camargo Aranha, por Decreto de 5 de Julho, lente substituto da I. ${ }^{a}$ Secção; tomou posse a I 2 do mesmo mez.

-Dr. Gabriel José Rodrigues de Rezende, por Decreto de 9 de Agosto, lente substituto da 6. ${ }^{a}$ Secção; tomou posse a I 4 do mesmo mez.

--Dr. Reynaldo Porchat, por Decreto de 18 de Outubro, lente substituto da I. ${ }^{2}$ Secção; tomou posse a 23 do mesmo mez. 
Fallecimentos:-Dr. Aureliano de Souza e Oliveira Coutinho, fallecido no dia 20 de Abril. Nomeado por Decreto de $2 \mathrm{I}$ de Março de I89I, lente da I. $^{a}$ cad. da $4 .^{a}$ Secção; tomou posse a 27 de Abril.

Nomeado por Decreto de 7 de Fevereiro de I 896 lente da $3 .^{a}$ cad. do $5 .^{\circ}$ anno em consequencia da reorganisação das Faculdades de Direito dada pelo Jecreto n.o 3 I4 de 30 de Outubro de 1895.

Tambem falleceram os academicos:

- Rossini Tavares de Lima ( $3 .^{a}$ série)

-Asdrubal de Lemos (2.. anno)

-Carlos de Almeida Prado (2..$^{a}$ série)

Curso Annexo:- Extincto em vista do $\S 3 .^{\circ}$ do art. 2. ${ }^{\circ}$ da lei n. 429 de io de Dezembro de 1896. 